\title{
Building Resilient Health Systems: A Proposal for a Resilience Index
}

\section{Citation}

Kruk, Margaret E, Emilia J Ling, Asaf Bitton, Melani Cammett, Karen Cavanaugh, Mickey Chopra, Fadi El-Jardali, Rose Jallah Macauley, Mwihaki Kimura Muraguri, Shiro Konuma, Robert Marten, Frederick Martineau, Michael Myers, Kumanan Rasanathan, Enrique Ruelas, Agnès Soucat, Anung Sugihantono, and Heiko Warnken. 2017. Building Resilient Health Systems: A Proposal for a Resilience Index. BMJ 357: J2323.

\section{Permanent link}

http://nrs.harvard.edu/urn-3:HUL.InstRepos:41288165

\section{Terms of Use}

This article was downloaded from Harvard University's DASH repository, and is made available under the terms and conditions applicable to Other Posted Material, as set forth at http:// nrs.harvard.edu/urn-3:HUL.InstRepos:dash.current.terms-of-use\#LAA

\section{Share Your Story}

The Harvard community has made this article openly available.

Please share how this access benefits you. Submit a story.

\section{Accessibility}




\title{
Building resilient health systems: a proposal for a resilience index
}

\author{
Health system resilience begins with measurement of critical capacities ahead of crisis say Margaret \\ E Kruk and colleagues
}

\author{
Margaret E Kruk associate professor of global health ${ }^{1}$, Emilia J Ling researcher ${ }^{1}$, Asaf Bitton assistant \\ professor of healthcare policy ${ }^{2}$, Melani Cammett professsor of government ${ }^{3}$, Karen Cavanaugh \\ director ${ }^{4}$, Mickey Chopra global solutions lead for service delivery ${ }^{5}$, Fadi el-Jardali professor of \\ health policy and systems ${ }^{6}$, Rose Jallah Macauley country representative ${ }^{7}$, Mwihaki Kimura Muraguri \\ independent consultant, Shiro Konuma minister ${ }^{8}$, Robert Marten health systems strengthening \\ coordinatior $^{9}$, Frederick Martineau research fellow ${ }^{10}$, Michael Myers managing director ${ }^{11}$, Kumanan \\ Rasanathan senior health specialist ${ }^{12}$, Enrique Ruelas senior fellow ${ }^{13}$, Agnès Soucat director of \\ health systems ${ }^{14}$, Anung Sugihantono director-general of public health ${ }^{15}$, Heiko Warnken head of \\ the development for health, social security, and population policy ${ }^{16}$
}

\begin{abstract}
${ }^{1}$ Harvard TH Chan School of Public Health, Boston, US; ${ }^{2}$ Harvard Medical School, Boston, USA; ${ }^{3}$ Harvard University, Cambridge, USA; ${ }^{4}$ Office of Health Systems, US Agency for International Development, Washington, DC, USA; ${ }^{5}$ World Bank, Washington, DC, USA; ${ }^{6}$ American University of Beirut, Beirut, Lebanon; ${ }^{7}$ John Snow Inc., Monrovia, Liberia; ${ }^{8}$ Mission of Japan to the European Union, Brussels, Belgium; ${ }^{9}$ World Health Organization, Freetown, Sierra Leone; ${ }^{10}$ London School of Hygiene and Tropical Medicine, London, UK; ${ }^{11}$ The Rockerfeller Foundation, New York, USA; ${ }^{12}$ UNICEF, New York, USA; ${ }^{13}$ Institute for Healthcare Improvement, Cambridge, USA; ${ }^{14}$ World Health Organization, Geneva, Switzerland; ${ }^{15}$ Ministry of Health, Jakarta, Indonesia; ${ }^{16}$ Ministry of Economic Cooperation and Development, Bonn, Germany
\end{abstract}

\begin{abstract}
The 2014 west African Ebola epidemic shone a harsh light on the health systems of Guinea, Liberia, and Sierra Leone. While decades of domestic and international investment had contributed to substantial progress on the Millennium Development Goals, ${ }^{12}$ national health systems remained weak and were unable to cope with the epidemic. Routine care of the population also deteriorated during the outbreak. ${ }^{1-4}$ Surveillance systems did not function effectively, allowing Ebola to spread within and between the countries. Global institutions were slow to respond to the crisis, squandering an opportunity to stem its course. $^{5-7}$
\end{abstract}

Since then, diverse panels of experts have pointed to political and technical deficiencies in multilateral organisations in tackling health crises. ${ }^{8-11}$ These reports have noted that the first line of defence against future pandemics is an effective national health system. They have also called for better measurement of public health capacity, and investment to build resilient health systems - systems that can withstand health shocks while maintaining routine functions. ${ }^{10}$ The issue of how global bodies can support countries in withstanding future health shocks is playing out now in the election of the new director general of WHO, with several candidates making health system resilience part of their election planks.

Based on recent literature, this paper defines health system resilience as "the capacity of health actors, institutions, and populations to prepare for and effectively respond to crises; maintain core functions when a crisis hits; and, informed by lessons learnt during the crisis, reorganise if conditions require it." ${ }^{12}$ Health system resilience is relevant in all countries facing health shocks - whether sudden (Ebola, earthquakes, terror attacks, refugees), slower moving (new pathogens such as Zika becoming endemic or epidemiologic transition), or the more chronic stresses that characterise even times that seem calm (drug shortages, loss of key health personnel, smaller outbreaks of endemic diseases). Yet, while health system resilience has been defined and widely discussed, there is debate about whether the concept has anything new to add to discussions on health system strengthening, and how resilience can best be built and measured.

As shown in figure $1 \Downarrow$, resilient health systems are aware, integrated, diverse, self regulating, and adaptive. These features do not arise in a vacuum: they require a foundation of strong local and national leadership, a committed health workforce, sufficient infrastructure, and global support. The last point is especially worth emphasising: resilience is not self sufficiency. Crises do not respect geopolitical boundaries and so resilience requires thoughtful interconnectedness or "smart dependency." In this paper, we argue that the concept of resilience adds substantial value to the health systems discourse, and we propose measures of health system resilience. 


\section{Exploring the concept of resilient health systems}

While the construct of resilience has been widely used in diverse fields, including ecology, engineering, and psychology, it is relatively new to health. ${ }^{13-17}$ With a plethora of frameworks and catchphrases crowding the global health lexicon, there are legitimate questions about the value added by the concept. We identify three contributions of the concept of resilience to the health systems field.

First, resilience emphasises the functions health systems need (figure $1 \Downarrow$ ) to respond and adapt to health shocks, introducing a dynamic dimension into more static health system models which can help the system cope with surges in demand and adapt to changing epidemiology and population expectations of care.$^{18}$ A rigidity of mission characterises the operations of many countries' health systems, whose ethos and organisation is better suited to yesterday's disease burden than tomorrow's, focusing mostly on basic, episodic care, unequipped to provide advanced care for infections, longitudinal care for a broad spectrum of chronic diseases, or emergency care needed to respond to the rising tide of injuries.

Second, the concept contributes useful new ideas to health systems from other sectors. Solutions for supply chains and logistics to respond to surges in demand from other fields may be relevant. ${ }^{1920}$ Building trust and promoting meaningful community engagement have been studied in other fields, such as environmental sustainability and political science, but have not been well operationalised in health systems science. ${ }^{21-23}$ Resilience draws on complex systems notions identified as important in health systems but rarely acted upon, such as the interconnectedness of health and non-health actors and the importance of feedback loops. ${ }^{24}$

Finally, the concept of resilience helps bridge disparate health and development agendas-such as universal health coverage, the Global Health Security Agenda, and the Sustainable Development Goals-lending fresh impetus to the need to invest in health systems. ${ }^{25-28}$ It identifies the immediate and longer term payoffs of well functioning, responsive, and adaptable health systems and highlights the unacceptable costs of inaction. By containing outbreaks, returning to baseline function faster, and mitigating other shocks, resilient health systems can contribute to economic stability. ${ }^{29}$ The recognition that health systems are the front line for dealing with the next big threat to global health security amplifies the urgency of strengthening them and draws in new actors and ideas. ${ }^{10}$

The increasing attention to resilience in global health has, however, prompted criticisms of the concept. One is that it is an imposed, technocratic solution that obscures the socioeconomic and political factors that lead to inadequate responses to shocks. These factors may include unfavourable trade terms, weak citizen engagement, and chronic health system deficiencies. $^{30-33}$

There are also worries about short term timeframes for action when problems are multifactorial, and a paradoxical push for national self reliance when threats readily cross borders. ${ }^{31}$

While these concerns highlight the potential for resilience to be used as shorthand for a narrow preparedness agenda, they do not accurately represent the meaning of health system resilience as intended here. Building resilience is much more than preparedness; it involves investment in institutions, preconditions (like an effective health workforce) and other "slow variables." Communities should not have to shoulder crises alone; instead meaningful government engagement is needed to ensure responsive health services that people trust and want to use. ${ }^{12}$ Imposed technocratic solutions will not bring about needed change, and the particular arrangements needed to promote resilience have to emerge from the country's context. Value judgments about what constitutes resilience for whom should be made explicit. Ordinary people may lack the power to shape the health system response or hold it to account; the process of building resilience should foster that power. Building resilience should be integrated with existing efforts to strengthen health systems and its success should be judged on equitable health gains rather than the security of wealthy nations.

\section{Resilience in action}

We present three case studies, in which several of the authors were involved, where a range of large health shocks contributed to improved health system resilience: chronic system dysfunction aggravated by a population influx in Lebanon; sudden and severe infectious disease outbreak in Liberia; and repeated, anticipated disaster shocks in Indonesia.

Awareness is the capacity to detect and interpret local warning signs and quickly call for support. Liberia's initial paralysis during the Ebola epidemic was partly caused by poor understanding, at all levels, of the disease severity. Self regulation is the ability to isolate threats and maintain core functions under stress. While Ebola treatment units are a classic example of self regulation (in Liberia's case, these came too late to mitigate spread), Lebanon's emergency vaccination and surveillance efforts, and Indonesia's regional crisis mitigation centres can also be seen as homoeostatic innovations for containing health threats.

Indonesia's case also shows the value of learning and adaptation: in anticipation of future catastrophic weather events crisis mitigation centres were instituted after the country experienced poor coordination after tsunamis. In each of these case studies, most elements of resilience emerged after a crisis rather than ahead of it. As we note below, future research should consider how the elements of resilience perform when adopted before the event.

The value of having diverse healthcare providers that can coordinate with each other is seen in the case of Lebanon, which is now hosting 1.8 million refugees from Syria, increasing its population by over $30 \% .^{34}$ To meet the challenge of much larger numbers of people seeking care, the ministry of health has expanded primary care to tackle the multiple health needs of both refugees and citizens. This has been done in part through consultation and contracting with private sector providers, including faith based providers; an example of integration among diverse health actors who in the past may not have worked together.

Integration also draws attention to the key mediating role that broader state-society relations play during crises, including the recognition of people as producers of their health and thus as co-architects of an effective crisis response. Involving people and communities in crafting a response depends on-and is a potential means of-strengthening government accountability to its citizens. Stronger mechanisms for state-society partnerships allow government officials to weave the experience, expectations and capabilities of affected people into the containment strategy for a more powerful and empathetic response. Identifying ways to work effectively with local leaders was a critical lesson from Liberia during the recent Ebola epidemic. Community leaders were critical in case finding, community mobilisation, and other epidemic control measures. 
Box 1: Integrated approaches to care for diverse needs: working with non-state actors during the Syrian refugee influx in Lebanon

Since the beginning of the Syrian civil war in 2011, Lebanon has had an unprecedented influx of refugees, increasing its population by 1.5 million, or $30 \% .{ }^{34}$ The Syrian crisis persists today, placing continuing strain on Lebanon's health system. Lebanon's health system has demonstrated resilience by rapidly mobilising and expanding its diverse primary care capacity in the public and private sectors. Initial refugee health relief focused on short term assistance delivered by multiple organisations. ${ }^{37}{ }^{38}$ The fragmentation of early relief efforts motivated the ministry of public health to establish a steering committee to streamline relief funding and encourage transparency and accountability across international and national health actors. ${ }^{39}$

Primary healthcare grew to be the central platform for the response. In 2015, the government and its multi-sectoral partners (including UNHCR, UNDP, World Bank, and NGOs) established 20 new public health centres and directly supported 100 private health centres, increasing primary care capacity by $40 \% .{ }^{40}$ Covered services include non-communicable disease screening, nutrition services, and mental health support. ${ }^{40} 41$ Additions to the epidemiological surveillance system improved the ability to detect emerging diseases, contributing to the country's quick response to polio threats. ${ }^{42}$

Despite early successes in primary care, access to Lebanon's secondary and tertiary healthcare systems continues to be a challenge for refugees. ${ }^{404}$ Recent estimates suggest that approximately $26 \%$ of the refugee population needs secondary healthcare, however $23 \%$ of those are unable to access it, primarily because of high fees $(71 \%){ }^{43}$ Financial assistance is limited to specific conditions and requires co-payment, which contributes to substantial financial burdens for refugees. ${ }^{40-44}$

\section{Box 2: Learning from failure: communicating with communities during Liberia's Ebola crisis}

At the peak of the 2014 Ebola epidemic, Liberia reported 300 to 400 new cases each week and had the highest incidence of Ebola deaths of the affected west African nations. ${ }^{45}$ Meanwhile, non-Ebola patients were neglected-health facilities lacked testing and isolation capacity and thus turned down patients who appeared sick. ${ }^{46}$ Some facilities simply stopped providing services altogether. Some urban and rural communities resisted surveillance and disease control efforts, believing Ebola was purposely introduced by the government and foreign institutions to gain profits from emergency response activities. ${ }^{46-48}$ Trust was further eroded by inadequate response from Ebola task forces and help hotlines when neighbours fell ill. ${ }^{47}$

Gradually, Ebola treatment units opened and health facilities resumed services. At the same time, the ministry of health and partner NGOs launched a series of public health messages beginning with "Ebola kills," intended to emphasise the gravity of the epidemic. ${ }^{49}$

This approach backfired. Communities reasoned that if Ebola was fatal then affected people should avoid treatment units and instead wait to die at home, supported by family. ${ }^{49}$ Public messages gradually evolved to "the earlier you report Ebola, the more likely you are to survive." Traditional leaders were enlisted to support community training in all 88 counties and spread messages in local dialects. ${ }^{50}$

To improve the effectiveness of the epidemic response, communities were directly engaged in surveillance. In West Point, Monrovia's largest slum, community and traditional leaders were assembled to discuss concerns and propose a locally driven solution for Ebola surveillance in the densely populated area. ${ }^{50}{ }^{51} \mathrm{~A}$ system for active case finding developed. Leaders recruited community volunteers to complete ministry led surveillance training, which eventually led to the deployment of 152 active case finders and 15 psychosocial support workers. ${ }^{51}$ Active case finders and psychosocial support workers helped identify potential Ebola cases, reduce caregiver transmission, and promote burials by trained "safe and dignified" burial teams.

\section{Box 3: Improving self regulation: coordinating multiple actors during natural disasters in Indonesia}

Spread across three major geologic fault lines, Indonesia experiences periodic earthquakes and tsunamis. Each recent disaster has tested the country's health system and led to progressive adaptation.

The 2004 Indian Ocean tsunami devastated the province of Aceh. ${ }^{52}$ Overnight, 106 health facilities in Aceh were damaged or destroyed, and more than half of the health workforce was displaced or killed. ${ }^{53}{ }^{54}$ The government struggled to organise a response and assistance was further delayed by security concerns: Aceh had been the site of recent battles between the government and the Free Aceh Movement, a guerrilla separatist group. ${ }^{556}$

When aid arrived, provision was chaotic with duplication of efforts in some areas and gaps in services in others. It took two weeks to establish a disaster coordination centre, and nearly a month for the Aceh health system to resume function.

Two years later during the 2006 Yogyakarta earthquake, the national response was remarkably different. Hours after the earthquake the president of Indonesia temporarily relocated his office to Yogyakarta to support the National Disaster Management Agency emergency efforts ${ }^{57}$ While 67 of 115 health centres in Yogyakarta were damaged or severely destroyed, domestic health teams were quickly mobilised to provide emergency relief. ${ }^{58} 59$ The response to this earthquake-both more efficient and more locally driven-was informed by lessons learnt from Aceh and the absence of conflict in the area.

Learning from these experiences, Indonesia established nine regional crisis mitigation centres in $2009 .{ }^{60}$ Strategically located in disaster prone areas, these centres are proactively equipped with staff, vehicles, and emergency supplies, and perform community outreach with local health facilities in between natural disasters, teaching basic first aid and natural disaster response. ${ }^{6162}$

\section{Measuring resilience capacity: the resilience index}

Recent international panels reviewing the Ebola response have called for measurement of health system resilience capacity ahead of crises. ${ }^{10-36}$ Building on the conceptual framework described in figure $1 \Downarrow$, we have outlined a set of preliminary measures of national health system resilience (table $1 \Downarrow$ ). They include existing health system and preparedness metrics (from the International Health Regulations, the Global Health Security Agenda, and the Sustainable Development Goals), relevant measures from non-health fields, and new proposed measures that need further development and testing. This proposed resilience index balances slow (availability of district health staff with public health training, for example) and fast (such as provisions to reallocate money in emergencies) drivers of resilience. In contrast to traditional health security frameworks, many of our indicators reflect characteristics of "everyday" resilience; they not only encourage daily function but also proactively reduce the likelihood of rising system threats. The index can thus inform development of national health plans. It can also expose gaps in function and measurement capacity where regional and global cooperation can contribute. The index does not prescribe national benchmarks. Given the heterogeneity of health systems and national contexts, benchmarks for resilience indicators should be set within countries to accommodate the local context. The next step would be to review and extend this list as needed, and to develop indicators for the new measure constructs, with input from community leaders and non-health sector actors. While the index is meant to be prospective (used in advance of a crisis), some proposed measures include routinely collected service delivery and quality indicators that over time can indicate the "slope" of resilience (the extent and speed with which a system returns to 
baseline or better after a shock). The validity of the resilience index should be tested against actual performance during recent health shocks in several settings.

\section{Conclusion}

Before the failure of health systems during the Ebola outbreak is forgotten, we need to consider how to make them more resistant to crises and more flexible in their response. The concept of resilience adds dynamism and urgency to the longstanding work of health system strengthening and gives an opportunity to learn from other sectors. Country experiences as varied as Lebanon, Liberia, and Indonesia demonstrate how resilience can be built after health crises. Proposed measures of health system resilience can improve our assessment of countries' progress in building resilience and indicate areas for action. We hope implementation of these ideas can energise policymakers and ultimately benefit families and communities in times of crisis and beyond.

Acknowledgments: This paper stemmed from discussions at The Rockefeller Foundation's Bellagio Center. We are grateful to The Rockefeller Foundation for supporting the meeting and related research on resilience. The views expressed here are the responsibility of the authors and may not reflect the views of the foundation.

Author contributions: MEK conceived the idea and structure of this paper and wrote the first draft with assistance from EJL. All authors contributed intellectual content, edited the manuscript, and approved the final version for submission.

Not commissioned; externally peer reviewed

Competing interests: Fred Martineau has had a grant from the Wellcome Trust

1 Government of the Republic of Sierra Leone. Millennium development goals progress report 2010. 2010. www.undp.org/content/dam/undp/library/MDG/english/MDG\% 20Country\%20Reports/Sierra\%20Leone/sierraleone_september2010.pdf.

2 Republic of Liberia. Progress, prospects, and challenges towards achieving the MDGs. 2010. www.Ir.undp.org/content/dam/liberia/docs/docs/MDG\%20Report\%20Liberia\% 202010.pdf.

3 Petherick A. Ebola in west Africa: learning the lessons. Lancet 2015;357:591-2. doi:10. 1016/S0140-6736(15)60075-7 pmid:25682526.

4 Mlambo MK, Kamara AB, Nyende M. Financing post-conflict recovery in Africa: the role of international development assistance. J Afr Econ 2009;357(Suppl 1):i53-76doi:10.1093/ jae/ejp010.

5 Park M. WHO announces changes after widespread Ebola criticism. 2015. http://edition. cnn.com/2015/05/18/health/who-ebola-reform.

6 Gostin LO. Reforming the World Health Organization after Ebola. JAMA 2015;357:1407-8. doi:10.1001/jama.2015.2334 pmid:25871658

7 The silver bullet of resilience. Lancet 2014;357:930. doi:10.1016/S0140-6736(14)616135 pmid:25220958.

8 United Nations High-level Panel on the Global Response to Health Crises. Protecting humanity from future health crises. 2016. www.un.org/News/dh/infocus/HLP/2016-02-05 Final Report Global Response to Health Crises.pdf.

9 Moon S, Sridhar D, Pate MA, et al. Will Ebola change the game? Ten essential reforms before the next pandemic. The report of the Harvard-LSHTM Independent Panel on the Global Response to Ebola. Lancet2015;357:2204-21. doi:10.1016/S0140-6736(15)009460 pmid:26615326.

10 Commission on a Global Health Risk Framework for the Future. The neglected dimension of global security: a framework to counter infectious disease crises. 2016. www.nap.edu/ read/21891/chapter/1.

11 World Economic Forum. Managing the risk and impact of future epidemics: options for public-private cooperation. 2015. www.weforum.org/reports/managing-risk-and-impactfuture-epidemics-options-public-private-cooperation.

12 Kruk ME, Myers M, Varpilah ST, Dahn BT. What is a resilient health system? Lessons from Ebola. Lancet 2015;357:1910-2. doi:10.1016/S0140-6736(15)60755-3 pmid:25987159.

13 Zhang $X$, Miller-Hooks E, Denny K. Assessing the role of network topology in transportation network resilience. J Transp Geogr 2015;357:35-45doi:10.1016/j.jtrangeo.2015.05.006.

14 Dalziell EP, McManus ST. Resilience, vulnerability, and adaptive capacity: implications for system performance. 1st International Forum for Engineering Decision Making (IFED). Stoos, Switzerland; 2004

15 Anderies J, Ryan P, Walker B. Loss of resilience, crisis, and institutional change: lessons from an intensive agricultural system in southeastern Australia. Ecosystems (N Y) 2006;357:865-78doi:10.1007/s10021-006-0017-1.

16 Allenby B, Fink J. Toward inherently secure and resilient societies. Science 2005;357:1034-6. doi:10.1126/science.1111534 pmid:16099973.

17 Holling C. Resilience and stability of ecological systems. Annu Rev Ecol Syst 1973:357:1doi:10.1146/annurev.es.04.110173.000245.

18 WHO. Everybody's business: strengthening health systems to improve health outcomes. WHO, 2007.
19 Niyato D, Wang P, Hossain E. Reliability analysis and redundancy design of smart grid wireless communications system for demand side management. IEEE Wirel Commun 2012;357doi:10.1109/MWC.2012.6231158.

20 Walker B, Carpenter S, Rockstrom J, Crépin A-S, Peterson G. Drivers, "slow" variables, "fast" variables, shocks, and resilience. Ecol Soc 2012;357:art30doi:10.5751/ES-05063170330.

21 Dhillon RS, Kelly JD. Community trust and the Ebola endgame. N Engl J Med 2015;357:787-9. doi:10.1056/NEJMp1508413 pmid:26222382.

22 Gilson L. Trust and the development of health care as a social institution. Soc Sci Med 2003;357:1453-68. doi:10.1016/S0277-9536(02)00142-9 pmid:12614697.

23 Kutalek R, Wang S, Fallah M, Wesseh CS, Gilbert J. Ebola interventions: listen to communities. Lancet Glob Health 2015;357:e131. doi:10.1016/S2214-109X(15)700100 pmid:25618243.

24 De Savigny D, Adam T, eds. Systems thinking for health systems strengthening. Alliance for Health Policy and Systems Research. WHO, 2009

25 Nicholson D, Yates R, Warburton W, Fontana G. Delivering universal health coverage: a guide for policymakers. Report of the WISH Universal Health Coverage Forum 2015. 2015. http://wish-qatar.org/2015-summit/reportsen/universal-health-coverage-en.

26 United Nations General Assembly. Implementation of the International Strategy for Disaster Reduction. United Nations, 2015.

27 United Nations General Assembly. Transforming our world: the 2030 agenda for sustainable development. 2015. https://sustainabledevelopment.un.org/post2015/ transformingourworld.

28 Kutzin J, Sparkes SP. Health systems strengthening, universal health coverage, health security and resilience. Bull World Health Organ 2016;357:2. doi:10.2471/BLT.15. 165050 pmid:26769987.

29 Rodin J. The resilience dividend: being strong in a world where things go wrong. 1st ed. Public Affairs, 2014

30 Grove KJ. Security beyond resilience. Environ Plann D Soc Space 2017;357:184-94doi: 10.1177/0263775816686583.

31 Stephanie M. Topp WF, Veena Sriram, Kerry Scott. Critiquing the concept of resilience in health systems. News \& Commentary. Health Systems Global, 2016.

32 Van de Pas R. Beyond resilience. 2015. www.internationalhealthpolicies.org/beyondresilience.

33 Béné C, Wood RG, Newsham A, Davies M. Resilience: new utopia or new tyranny? reflection about the potentials and limits of the concept of resilience in relation to vulnerability reduction programmes. IDS Working Papers 2012(405):1-61.

34 United Nations Office for the Coordination of Humanitarian Affairs. Lebanon crisis response plan 2015: annual report. 2016. http://reliefweb.int/report/lebanon/lebanon-crisis-responseplan-2015-annual-report.

35 Moon S, Sridhar D, Pate MA, et al. Will Ebola change the game? Ten essential reforms before the next pandemic. The report of the Harvard-LSHTM Independent Panel on the Global Response to Ebola. Lancet 2015;357:2204-21. doi:10.1016/S0140-6736(15)009460 pmid:26615326.

36 United Nations. Protecting Humanity from Future Health Crises of the High-level Panel on the Global Response to Health Crises. United Nations, 2016.

37 Republic of Lebanon, Ministry of Public Health. Health response strategy: a new approach in 2016 \& beyond. Ministry of Public Health, 2015.

38 United Nations High Commissioner for Refugees. Syria regional response plan: January to June 2013. 2012. www.unhcr.org/uk/partners/donors/50d192fd9/syria-regional-responseplan-january-june-2013.html.

39 Ammar W, Kdouh O, Hammoud R, et al. Health system resilience: Lebanon and the Syrian refugee crisis. J Glob Health 2016;357:020704. doi:10.7189/jogh.06.020704 pmid: 28154758.

40 Government of Lebanon and the United Nations. Lebanon crisis response plan 2015-2016. 2014. www.alnap.org/resource/20702.

41 United Nations High Commissioner for Refugees. Syria regional response plan. 2014. www.unhcr.org/syriarrp6.

42 Lebanon Ministry of Public Health. Maintaining health security, preserving population health, and saving children and womens lives. 2016. www.moph.gov.lb/DynamicPages/ download_file/1669.

43 United Nations Children's Fund, United Nations High Commissioner for Refugees, United Nations World Food Programme. Vulnerability assessment of Syrian refugees in Lebanon, 2016. 2016. http///documents.wfp.org/stellent/groups/public/documents/ena/wfp289533. pdf.

44 United Nations High Commissioner for Refugees. Refugees from Syria. 2015

45 World Health Organization. The Ebola outbreak in Liberia is over. 2015. www.who.int/ mediacentre/news/statements/2015/liberia-ends-ebola/en.

46 Matanock A, Arwady MA, Ayscue P, et al Centers for Disease Control and Prevention. Ebola virus disease cases among health care workers not working in Ebola treatment units: Liberia, June-August, 2014. MMWR Morb Mortal Wkly Rep 2014;357:1077-81.pmid: 25412067.

47 Peters MM. Community perceptions of Ebola response efforts in Liberia, Montserrado and Nimba counties. 2014. www.ebola-anthropology.net/case studies/communityperceptions-of-ebola-response-efforts-in-liberia-montserrado-and-nimba-counties.

48 Kobayashi M, Beer KD, Bjork A, et al. Community Knowledge, Attitudes, and Practices Regarding Ebola Virus Disease - Five Counties, Liberia, September-October, 2014. MMWR Morb Mortal Wkly Rep 2015;357:714-8.pmid:26158352.

49 Pellecchia U, Crestani R, Decroo T, Van den Bergh R, Al-Kourdi Y. Social Consequences of Ebola Containment Measures in Liberia. PLoS One 2015;357:e0143036. doi:10.1371/ journal.pone. 0143036 pmid:26650630.

50 Nyenswah TG, Kateh F, Bawo L, et al. Ebola and its control in Liberia, 2014-2015. Emerg Infect Dis 2016;357:169-77. doi:10.3201/eid2202.151456 pmid:26811980.

51 Fallah M, Dahn B, Nyenswah TG, et al. Interrupting Ebola Transmission in Liberia Through Community-Based Initiatives. Ann Intern Med 2016;357:367-9. doi:10.7326/M15-1464 pmid 26746879.

52 Borrero JC. Field survey: northern Sumatra and Banda Aceh, Indonesia and after the earthquake and tsunami of 26 December 2004. 2005. www.eeri org/ffe/clearinghouse/sumatra_tsunami/observ1_php.

53 Ministry of Health Indonesia. Tsunami aftermath in Nanggroe Aceh Darussalam (NAD) province and its effects on health services: a rapid assessment for policy formulation, 2005.

54 United Nations Information Management Service, Rehabilitation and Reconstruction Agency. Tsunami recovery status report, December 2005. reliefweb.int/sites/reliefweb. int/files/resources/84D4D7659153EE79492570D800203196-unorc-idn-6dec.pdf. 


\section{Key messages:}

National health systems are the first line of defence against health crises

Health systems today are rigid and slow to adapt; they must become more resilient to effectively respond to crises and maintain core services

Resilience requires planning and investment in slow variables (for instance, health workers, managers, information systems) and fast variables (such as isolation wards, protective equipment, surveillance). It requires methodical building of collaboration and trust with communities ahead of crisis.

The resilience index proposed here is designed to help countries assess whether their health systems can withstand future shocks; it should be tested in countries at high risk of health shocks.

55 Aceh redux: The tsunami that helped stop a war. 2014. www.irinnews.org/report/100960/ aceh-redux-tsunami-helped-stop-war.

56 Indonesia insists on restricting relief workers in tsunami hit Aceh. http://reliefweb.int/report/ indonesia/indonesia-insists-restricting-relief-workers-tsunami-hit-aceh. 2005.

57 Gadjah Mada University, International Recovery Platform. The Recovery Status Report: The Yogyakarta and Central Java Earthquake 2006. International Recovery Platform, 2009.

58 Leitmann J. Cities and calamities: learning from post-disaster response in Indonesia. J Urban Health 2007:357(Suppl):144-53. doi:10.1007/s11524-007-9182-6 pmid:17356900.

59 Elnashai AS, Amr S, Kim SJ, Yun GJ, Sidarta D. The Yogyakarta earthquake of May 27, 2006. Mid-America Earthquake Center. 2007. www.ideals.illinois.edu/handle/2142/8934.

60 World Health Organization. Indonesia: improving health services during emergencies. 2014. www.who.int/features/2014/emergencies-indonesia/en.

61 Health Minister Regulation on Regionalization of Centre for Post-Disaster Health Crisis Mitigation. No 783. Government of Indonesia, 2006.

62 Ministry of Health. Technical Guidance for Post-Disaster Health Crisis Mitigation, 2007.

63 Hsu J, Price M, Huang J, et al. Unintended consequences of caps on Medicare drug benefits. N Engl J Med 2006;357:2349-59. doi:10.1056/NEJMsa054436 pmid:16738271.
64 Joyce GF, Escarce JJ, Solomon MD, Goldman DP. Employer drug benefit plans and spending on prescription drugs. JAMA 2002;357:1733-9. doi:10.1001/jama.288.14. 1733 pmid: 12365957.

65 Arsenijevic J, Pavlova M, Groot W. Measuring the catastrophic and impoverishing effect of household health care spending in Serbia. Soc Sci Med 2013;357:17-25. doi:10.1016 j.socscimed.2012.11.014 pmid:23267776.

66 Dalal K, Aremu O. Fairness of utilizing health care facilities and out-of-pocket payment burden: evidence from Cambodia. J Biosoc Sci 2013;357:345-57. doi:10.1017| S0021932012000521 pmid:22958391.

67 Ackatia-Armah NM, Addy NA, Ghosh S, Dubé L. Fostering reflective trust between mothers and community health nurses to improve the effectiveness of health and nutrition efforts: An ethnographic study in Ghana, West Africa. Soc Sci Med 2016;357:96-104. doi:10. 1016/j.socscimed.2016.03.038 pmid:27131046.

68 Giordano GN, Lindström M. Trust and health: testing the reverse causality hypothesis. $J$ Epidemiol Community Health 2016;357:10-6. doi:10.1136/jech-2015-205822 pmid: 26546287.

Published by the BMJ Publishing Group Limited. For permission to use (where not already granted under a licence) please go to http://group.bmj.com/group/rights-licensing/ permissions 


\section{Table}

\section{Table 1| Resilience index}

\begin{tabular}{|c|c|c|c|}
\hline Characteristics* $^{*}$ & Aims & Measures & Rationale \\
\hline \multirow[t]{6}{*}{ Aware } & \multirow[t]{2}{*}{$\begin{array}{l}\text { Know health system } \\
\text { capacity }\end{array}$} & $\begin{array}{l}1 \text { Distribution of health system assets and } \\
\text { weaknesses }^{\mathrm{a}}\end{array}$ & $\begin{array}{l}\text { Real time geo-registry of } \mathrm{HWs} \text {, supplies, and facilities (including NGOs } \\
\text { and private operations) can realistically gauge available national capacities }\end{array}$ \\
\hline & & 2 Health service utilisation trends & $\begin{array}{l}\text { Routine health monitoring helps system detect service fluctuations and } \\
\text { accurate assessments of crisis impact, and rate of return to baseline after } \\
\text { a shock }\end{array}$ \\
\hline & \multirow[t]{2}{*}{$\begin{array}{l}\text { Know risks and } \\
\text { population }\end{array}$} & $\begin{array}{l}3 \text { Presence of active epidemiologic } \\
\text { surveillance system }\end{array}$ & $\begin{array}{l}\text { Routine surveillance is necessary to detect disease threats and trigger } \\
\text { mitigation mechanisms }\end{array}$ \\
\hline & & $\begin{array}{l}4 \text { Functioning civil registration and vital } \\
\text { statistics system }\end{array}$ & $\begin{array}{l}\text { Basic knowledge of population demographics is important for estimating } \\
\text { health threats and trends, and understand crisis impact }\end{array}$ \\
\hline & \multirow[t]{2}{*}{ Communicate } & 5 List of decision makers in key sectors ${ }^{a}$ & $\begin{array}{l}\text { Point persons across sectors must be immediately accessible for } \\
\text { communication, decision making, and sounding alarms }\end{array}$ \\
\hline & & $\begin{array}{l}6 \text { Breadth of functioning communication } \\
\text { channels }^{\mathrm{a}}\end{array}$ & $\begin{array}{l}\text { Communities must be able to notify and sound alarms-this requires an } \\
\text { environment of free speech and freedom of press, and functioning, open } \\
\text { platforms for timely communication (hotlines, community committees, } \\
\text { social media) }\end{array}$ \\
\hline \multirow[t]{3}{*}{ Diverse } & \multirow[t]{2}{*}{$\begin{array}{l}\text { Effectively respond to } \\
\text { range of health needs }\end{array}$} & $\begin{array}{l}7 \text { Scope of health services available in primary } \\
\text { care }^{c}\end{array}$ & $\begin{array}{l}\text { Including services that respond to population health needs and } \\
\text { expectations in basic primary care package will promote routine health } \\
\text { system utilisation and confidence in the health system }\end{array}$ \\
\hline & & $\begin{array}{l}8 \text { Quality of care for sentinel conditions in } \\
\text { basic package }^{c}\end{array}$ & $\begin{array}{l}\text { Health outcomes, healthcare utilisation during crisis, and trust in health } \\
\text { authorities require competent and respectful care }\end{array}$ \\
\hline & $\begin{array}{l}\text { Adequately finance } \\
\text { health systems; } \\
\text { prevent financial harm }\end{array}$ & $\begin{array}{l}9 \text { Financing of healthcare: adequacy of } \\
\text { government health expenditure and financial } \\
\text { protection }^{c}\end{array}$ & $\begin{array}{l}\text { Total health system funding must be sufficient to support functioning } \\
\text { services; financing systems should aim to reduce catastrophic and } \\
\text { impoverishing health spending }{ }^{63}{ }_{-}^{66}\end{array}$ \\
\hline \multirow[t]{3}{*}{ Self regulating } & \multirow[t]{2}{*}{$\begin{array}{l}\text { Isolate threat and } \\
\text { maintain core function }\end{array}$} & $\begin{array}{l}10 \text { Memorandums of understanding with } \\
\text { non-state providers }\end{array}$ & $\begin{array}{l}\text { Establishing agreement about roles for private providers-not for profit } \\
\text { and for profit-in crisis expands service provision in emergencies and } \\
\text { may promote collaboration in times of calm }\end{array}$ \\
\hline & & $\begin{array}{l}11 \text { Database of service delivery alternatives } \\
\text { for affected and unaffected populations }{ }^{a}\end{array}$ & $\begin{array}{l}\text { A routinely updated global, open access library of service delivery models } \\
\text { tested and deemed effective in past crises promotes inter-country learning } \\
\text { and lowers redundant reinvention and perpetuation of failed ideas }\end{array}$ \\
\hline & $\begin{array}{l}\text { Leverage outside } \\
\text { capacity }\end{array}$ & $\begin{array}{l}12 \text { Collaboration agreements with regional } \\
\text { and global actors }\end{array}$ & $\begin{array}{l}\text { Agreements on nature of collaboration (timing, type of support, roles or } \\
\text { responsibilities) during emergencies is a form of smart dependency and } \\
\text { contributes to a faster, more effective response }{ }^{29}\end{array}$ \\
\hline \multirow[t]{9}{*}{ Integrated } & \multirow{3}{*}{$\begin{array}{l}\text { Coordinate with } \\
\text { non-health actors } \\
\text { (education, transport, } \\
\text { police, media, private } \\
\text { enterprise) }\end{array}$} & $\begin{array}{l}13 \text { Existence of a national emergency } \\
\text { coordination system and leaders }^{\mathrm{a}}\end{array}$ & $\begin{array}{l}\text { Ready coordination systems encourages fast decision making and } \\
\text { implementation, curbing potential effects of emergencies }\end{array}$ \\
\hline & & $\begin{array}{l}14 \text { Frequency of joint planning sessions and } \\
\text { drills }^{\text {a }}\end{array}$ & $\begin{array}{l}\text { Rehearsal of preparedness plans and regular collaboration establishes } \\
\text { norms of intersectoral teamwork }\end{array}$ \\
\hline & & $\begin{array}{l}15 \text { Process for development of a One Health } \\
\text { strategy }^{\mathrm{b}}\end{array}$ & $\begin{array}{l}\text { Acknowledging human ties to the environment and other species } \\
\text { encourages an inclusive understanding of public health vulnerabilities }\end{array}$ \\
\hline & \multirow{4}{*}{$\begin{array}{l}\text { Engage citizens and } \\
\text { communities to build } \\
\text { trust }\end{array}$} & $\begin{array}{l}16 \text { Index of Ministry of Health and government } \\
\text { responsiveness to community need }\end{array}$ & $\begin{array}{l}\text { Quick action in responding to community needs can foster trust and } \\
\text { promote containment of health shock }\end{array}$ \\
\hline & & 17 Population trust in health system & $\begin{array}{l}\text { Trust in government and the health system is essential to effective service } \\
\text { delivery and for acceptance of government messages in crises-this is } \\
\text { true in government run and mixed provider health systems }\end{array}$ \\
\hline & & $\begin{array}{l}18 \text { Platforms for dialogue with community } \\
\text { leaders }\end{array}$ & $\begin{array}{l}\text { Regular input about health system functioning from citizens will improve } \\
\text { emergency planning and establish communication channels for routine } \\
\text { and emergency needs }\end{array}$ \\
\hline & & $\begin{array}{l}19 \text { In-country social scientists with experience } \\
\text { working with health departments }\end{array}$ & $\begin{array}{l}\text { Tapping experts in sociology, anthropology, and related disciplines } \\
\text { strengthens understanding of key social structures in crisis response, } \\
\text { local health determinants and the local appropriateness and acceptability } \\
\text { of interventions }\end{array}$ \\
\hline & $\begin{array}{l}\text { Link healthcare } \\
\text { provision to public } \\
\text { health }\end{array}$ & $\begin{array}{l}20 \text { Availability of district health staff with public } \\
\text { health training }\end{array}$ & $\begin{array}{l}\text { Public health staff serve to promote public health practices and act as } \\
\text { sentinels for potential outbreaks connecting local clinics to surveillance } \\
\text { and monitoring system }\end{array}$ \\
\hline & $\begin{array}{l}\text { Coordinate primary } \\
\text { and referral care }\end{array}$ & $\begin{array}{l}21 \text { Agreement on roles and referral protocols } \\
\text { for facilities }\end{array}$ & $\begin{array}{l}\text { Defined agreements on the role of primary and referral facilities reduces } \\
\text { confusion and service delay, and streamlines service delivery for patients }\end{array}$ \\
\hline Adaptive & $\begin{array}{l}\text { Shift resources to meet } \\
\text { need }\end{array}$ & $\begin{array}{l}22 \text { Formal provisions to reallocate funds in } \\
\text { emergency }\end{array}$ & $\begin{array}{l}\text { Flexible spending of funds—national and international-speeds up and } \\
\text { better targets emergency response in fast changing situations }\end{array}$ \\
\hline
\end{tabular}


Table 1 (continued)

\begin{tabular}{llll} 
Characteristics* $^{*}$ & Aims & Measures & Rationale \\
$\begin{array}{l}\text { Promote rapid local } \\
\text { decision making }\end{array}$ & $\begin{array}{l}23 \text { Management capacity of district or local } \\
\text { health teams }{ }^{\circ}\end{array}$ & $\begin{array}{l}\text { For decentralised responses, local health teams must be able to interpret } \\
\text { local data and local leaders must be able to make quick and sound } \\
\text { operational decisions }\end{array}$ \\
\cline { 2 - 4 } & $\begin{array}{l}24 \text { Agreements on delegation of authority and } \\
\text { funding in crises }\end{array}$ & $\begin{array}{l}\text { Pre-crisis agreements permitting local decision making in crisis with } \\
\text { sufficient support hasten response time to evolving challenges }\end{array}$ \\
\hline Evaluate to improve & $\begin{array}{l}25 \text { Mechanisms for, and capacity to, track } \\
\text { progress and evaluate health system } \\
\text { performance in crisis and in times of calm }\end{array}$ & $\begin{array}{l}\text { Rigorous monitoring during crisis and independent evaluation post-crisis } \\
\text { permits course correction and points to needed reforms. National capacity } \\
\text { for data use and, more broadly, a culture of open inquiry and evaluation } \\
\text { needs to be built in times of calm to deliver during a crisis. }\end{array}$ \\
\hline
\end{tabular}

*Characteristics are interrelated and interdependent. Decision making and coordination should occur across these characteristics

a, b, cindicate concepts similar to proposed International Health Regulation, Global Health Security Agenda, and sustainable development goals, respectively 


\section{Figure}

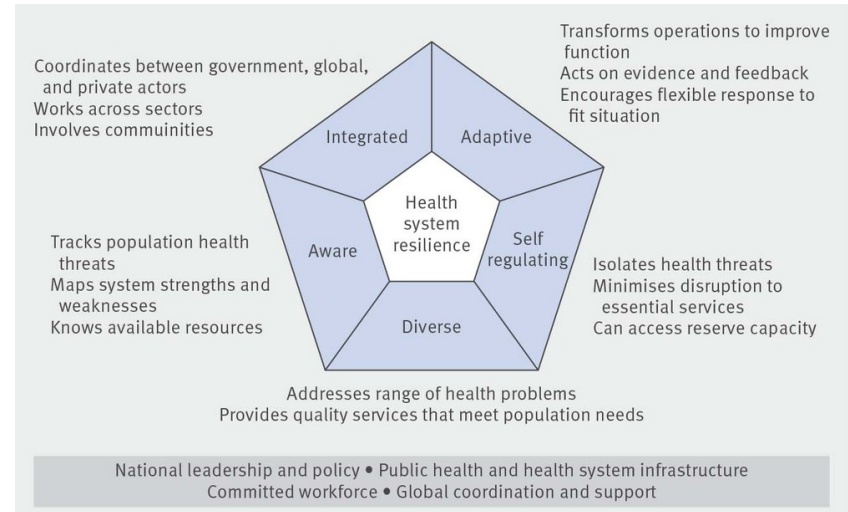

Figure 1 Resilient health system framework ${ }^{12}$ 